\section{Sprawiedliwość epistemiczna w humanistyce zaangażowanej}

Ewa Domańska
Artykułzostał przygotowany w ramach grantu Narodowego Centrum Nauki przyznanego na podstawie decyzji DEC-2013/ IIIB/HS3/02075.
$\mathbf{W}$ artykule tym chciałabym zasygnalizować trzy łączące się ze sobą kwestie, które uważam za ważne w kontekście zarówno dyskusji na temat statusu i roli humanistyki (a zwłaszcza tzw. nowej humanistyki) wśród innych dziedzin wiedzy i w systemie edukacji, jak i w toczących się obecnie na świecie dyskusji dotyczących istotnych rekonfiguracji w celach i sposobach budowania wiedzy. Wśród nich szczególnie ostatnio angażujące są rozważania na temat sprawiedliwości i niesprawiedliwości epistemicznej. W tym kontekście proponuję podjęcie kwestii humanistyki, którą chciałabym określić jako prefiguratywną, a także poddać pod dyskusję zagadnienie „nauki powolnej” (czy nieśpiesznej) (slow science).

Będę starała się wykazać, że istnieje ważna współzależność między ideą „nauki powolnej” (czy nieśpiesznej) (slow science $)^{1}$, tj. kładącej nacisk na jakość prowadzonych

1 Odpowiednie tłumaczenie określenia slow science jest strategiczne i trudne. Nie chodzi tutaj bowiem o naukę ślamazarną, niemrawą, flegmatyczną, gnuśną, co sugerowałoby przyzwolenie na lenistwo intelektualne, ale o prowadzenie badań naukowych bez pośpiechu, rozważnie, spokojnie, odpowiedzialnie, z czasem do namysłu i na korektę błędów. Można zatem mówić tutaj o nauce powolnej, nieśpiesznej czy/i rozważnej.

\section{Ewa Domańska}

- profesor nauk humanistycznych w Instytucie Uniwersytetu im. Adama Mickiewicza oraz od 2002 visiting associate professor w Department of Anthropology, Stanford University. Zajmuje się współczesną teorią i historią historiografii oraz porównawczą teorią nauk humanistycznych. Autorka i redaktorka kilkunastu książek, m.in. Historia egzystencjalna (2012); Historia - dziś (red. z R. Stobieckim iT. Wiśliczem, 2014) oraz Nekros: Wprowadzenie do ontologii martwego ciała (2017, w druku). 
badań oraz formacyjną rolę uczenia i praktykowania badań naukowych, i kwestią sprawiedliwości epistemicznej² i zwróconej ku przyszłości humanistyki prefiguratywnej. Proponuję także, by uznać sprawiedliwość epistemiczną za dyrektywę sterującą prowadzonymi w ramach tej humanistyki badaniami. Jednocześnie sprawiedliwość epistemiczną można też uznać za jeden ze środków w procesie budowania realistycznych i odpowiedzialnych utopii, których pierwowzory „nowa humanistyka” próbuje odnaleźć w sztuce, literaturze, filmie itd. Idea takiej utopii, jako powtarzalny sposób rozwiązywania problemu naukowego, może stać się charakterystyczną dla „nowej humanistyki" metodą badań.

Jednym z ważnych celów humanistyki prefiguratywnej, pomocnym w budowaniu alternatywnych wizji przyszłości (realistycznych utopii), byłoby, jak sądzę, kreowanie krytycznej nadziei, którą uznaję tutaj strategicznie za obowiazek humanisty stojącego w obliczu realnych zagrożeń (terroryzm, problemy stwarzane przez procesy migracyjne, wzrastający poziom biedy, kryzys demokracji, a także zmiany klimatyczne, problemy środowiskowe itd.). Działając zgodnie z duchem postsekularyzmu, powiem także, że pomocne w realizacji tego celu może być przemyślenie idei „tekstualnej magii” i tworzenie tekstów humanistycznych (w szerokim tego słowa znaczeniu - tekstów kulturowych) jako "tekstów apotropaicznych"3 tj. osłaniających kulturę, odsuwających

2 Zgodnie z ideami humanistyki afirmatywnej bardziej interesuje mnie tworzenie humanistyki sprawiedliwej niż wykazywanie niesprawiedliwości istniejącej. Rzecz jasna, w praktyce rozróżnienie to nie jest takie oczywiste, chodzi jednak o podkreślenie aspektu przyszłościowego projektu i skupianie się nie tyle na krytyce istniejącego systemu, ale biorąc za punkt wyjścia jej efekty, próba budowania lepszego. Projekt ten w żadnym razie nie optuje za porzuceniem krytyki, choć można się zastanowić, w jakim sensie stanowi on symptom kondycji „post-krytycznej”. Zob. E. Domańska Humanistyka afirmatywna: płeć i władza po Butler i Foucaulcie, „Kultura Współczesna" 2014 nr 4, s.117-129. Por. także: H. Foster Post-krytyczność, przeł. A. Regulska, "Teksty Drugie" 2015 nr 6, s. 160-168; Criticism after Critique: Aesthetics, Literature, and the Political, ed. by J.R. Di Leo, Palgrave Macmillan, New York 2014.

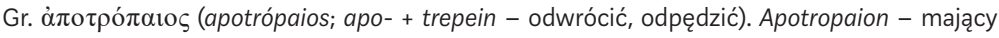
właściwości magiczne przedmiot chroniący przed złem. Ma on moc odwrócenia zła czy złych wpływów, a także odsuwania gróźb i zagrożeń. Zazwyczaj w formie amuletu czy talizmanu, przedmiot broniący przed złymi duchami, klęskami, chorobami. Apotropaizm jest rodzajem magii obronnej, która posługuje się zaklęciami, amuletami, dzwonkami, a także wodą święconą czy krzyżem w celu odpędzenia zła. Od wieków znany jest rodzaj tekstów określanych jako apotropaiczne, które działają jak amulety (np. cytaty ze świętych ksiąg różnych religii działają jak inskrypcje ochronne; rodzajem takich tekstów są także modlitwy, np. o uzdrowienie). Na podobnej zasadzie działają także apotropaiczne rzeźby. Zob.: J. Rajchel Kamienne apotropaiczne rzeźby w architekturze Krakowa, "Przegląd Geologiczny” 2014 t. 62, nr 3, s. 156-162; 
możliwości różnych katastrof przez tworzenie warstwy ochronnej w postaci specyficznego imaginarium społecznego (alternatywnych wizji przyszłości ukazujących różne możliwości współ-bycia i współ-życia społecznego, a także promowanie postaw pożądanych dla realizacji tych możliwości $)^{4}$. W tym sensie humanistyka prefiguratywna, potrzebna zwłaszcza w czasach nasilających się konfliktów i zagrożeń, byłaby rodzajem praktyki ochronnej. Jej celem byłoby prewencyjne działanie ante factum, a nie post factum, na zasadzie "egzorcyzmów", co wydaje się charakterystyczne dla wielu dyskursów politycznych i towarzyszących im badań pamięci próbujących odczyniać zło, do którego już doszło. Zaklinanie przyszłości formułami w stylu „nigdy więcej”, jak brutalnie pokazuje rzeczywistość, nie ma żadnej mocy perfomatywnej, a jedynie życzeniową. Można zastanowić się zatem, jakie to warunki niezbędne powinny zostać spełnione, by przywrócić tym słowom moc sprawczą.

\section{Nie/sprawiedliwość epistemiczna}

Problem niesprawiedliwości epistemicznej stanowi jedną z najważniejszych kwestii podejmowanych w ramach humanistyki zaangażowanej. Dotyczy on relacji między władzą i wiedzą oraz związków między nie/sprawiedliwością epistemiczną i społeczną. Sam termin został jednak wprowadzony niedawno przez Mirandę Fricker, która w 2007 roku opublikowała książkę Epistemic Injustice: Power and the Ethics of Knowing. Praca ta wywołała ożywione dyskusje dotyczące różnych sposobów niesprawiedliwego traktowania podmiotów poznających i podmiotów poznania ze względu na ich rasę, płeć, wiek, status społeczny itd. Chodzi o to, że - jak twierdzi Fricker, współczesnej epistemologii „brakuje teoretycznej ramy, która pozwoliłaby odsłonić etyczne i polityczne aspekty naszych epistemicznych zachowań"5. Temat, rzecz jasna,

P. Lasek O apotropaicznej funkcji niektórych kaplic zamkowych w średniowiecznej Polsce - zarys problematyki, Stowarzyszenie Historyków Sztuki, oddział w Poznaniu, 28.06.2008, http://www. shs.poznan.pl/index.php?option=com_content\&task=view\&id $=45 \&$ Itemid $=48 \&$ limit $=1 \& \mathrm{li}-$ mitstart $=0$ (23.06.2016); D.C. Skemer Binding Words: Textual Amulets in the Middle Ages. University Park: Pennsylvania State University Press, 2006; Stephan Peter Bumbacher, Empowered Writing: Exorcistic and Apotropaic Rituals in Medieval China, Three Pines Press, 2012; M.Taussig The Corn-Wolf: Writing Apotropaic Texts, "Critical Inquiry” 2010 Vol. 37, No. 1, s. 26-33.

4 O powieści jako rodzaju apotropaicznej obrony pisze A. Houen Novel Spaces and Taking Place(s) in the Wake of September 11, "Studies in the Novel" Fall 2004 Vol. 36, No. 3, s. 421.

5 M. Fricker Epistemic Injustice: Power and the Ethics of Knowing, Oxford University Press, Oxford 2007, s. 2. Zob. także: dyskusja nad książką: Forum: Miranda Fricker's Epistemic Injustice. Power 
nie jest nowy, a ważne głosy w tej sprawie od dawna pojawiały się zwłaszcza ze strony epistemologii feministycznej (reprezentowanej m.in. przez Susan Bordo, Donnę Haraway, Sandrę Harding i Helen Longino). Ciekawe jest jednak jego ujęcie w perspektywie epistemologii cnoty (związanej z filozofią analityczną), która zdaniem autorki dostarcza wspólnego idiomu dla dyskusji na ten temat ${ }^{6}$. Przez wprowadzenie specyficznego dla filozofii analitycznej języka i stylu myślenia zmienia się zatem sposób ujęcia problematyki. Dotychczas był on zdominowany przez podejścia poststrukturalistyczne, których manifestacją są kanoniczne prace Michela Foucaulta na temat relacji savoir-pouvoir. Kładzie się nacisk na ostrożny i krytyczny sposób badania, jasne i precyzyjne myślenie i formułowanie sądów, promuje się rozwiązywanie problemu badawczego na drodze drobiazgowych analiz problemów szczegółowych, podejmuje się kwestie obiektywizmu badań naukowych i dystansu poznawczego.

Fricker wyróżnia dwa zasadnicze rodzaje niesprawiedliwości epistemicznej związanej z niekorzystną sytuacją, w której znajduje się podmiot poznania: są to niesprawiedliwość świadczenia i niesprawiedliwość hermeneutyczna.

Niesprawiedliwość świadczenia (testimonial injustice) występuje, kiedy uprzedzenia słuchającego wpływają na postrzeganie poziomu wiarygodności słów mówiącego; niesprawiedliwość hermeneutyczna (hermeneutical injustice) ma miejsce na poprzednim etapie, kiedy luka w zbiorowej bazie interpretacji stawia kogoś w niekorzystnej sytuacji jeżeli chodzi o nadawanie sensu doświadczeniom społecznym. Przykładem pierwszej może być sytuacja, kiedy policja nie wierzy osobie, ponieważ jest czarna; a drugiej - kiedy ktoś cierpi z powodu molestowania seksualnego w kulturze, która nie rozwinęła krytycznego podejścia do tego pojęcia. Można powiedzieć, że niesprawiedliwość świadczenia powodowana jest ekonomią wiarygodności, a niesprawiedliwość hermeneutyczna przez strukturalne uprzedzenia funkcjonujące w zbiorowej gospodarce środków hermeneutycznych.?

and the Ethics of Knowing, Theoria 2008 Vol. 23, No. 1. Por. także A. Catala Democracy, Trust, and Epistemic/ustice, "The Monist" October 2015 Vol. 98, No. 4, s. 424-440.

6 M. Fricker Epistemic Injustice..., s. 2.

7 Tamże, s. 1. 
Nie będę tutaj rozpatrywać szczegółów koncepcji Fricker. Dla celów prowadzonych w tym tekście rozważań zaznaczę jedynie istotny dla idei nie/ sprawiedliwości epistemicznej aspekt epistemologii cnoty: opiera się ona na podmiocie, a dokładniej na własności podmiotów poznania, które są podmiotami moralnymi. Jest to nurt zróżnicowany, ale główni przedstawiciele najbardziej popularnych podejść: John Greco i Linda Zagzebski utrzymują, że posiadane przez nie cnoty intelektualne (takie jak m.in. odwaga intelektualna, odpowiedzialność, opanowanie intelektualne, bezstronność, sumienność, konsekwencja) są zasadnicze dla tworzenia wartościowej wiedzy, a nawet ją warunkują. Zagzebski „za wiedzę uznaje prawdziwe przekonanie wyrastające z aktów cnoty intelektualnej". Wynika z tego, że - jak twierdzi inny przedstawiciel epistemologii cnoty - John Greco: „S wie, że $p$ tylko wtedy, gdy żywienie tego przekonania wynika z cnotliwego charakteru poznawczego"8. Upraszczając, można zatem powiedzieć, że w świetle tego nurtu np. historyk nie będzie tworzył obiektywnej i wiarygodnej wiedzy o przeszłości, jeżeli nie jest osobą odznaczającą się takimi cnotami intelektualnymi jak bezstronność czy/i prawdomówność.

\section{Epistemiczne nieposłuszeństwo}

Chciałabym ulokować zagadnienie nie/sprawiedliwości epistemicznej w kontekście studiów postkolonialnych i dyskusji na temat geopolityki wiedzy. Argentyński badacz - Walter D. Mignolo, który od wielu już lat zwraca uwagę na relacje między kwestią geopolityki wiedzy i niesprawiedliwością epistemiczną, twierdząc, że

8 J. Greco Epistemologia cnoty, przeł. B. Męczyński, „Hybris. Internetowy Magazyn Filozoficzny" 2005 t. 3, http://magazynhybris.com/index.php/archiwum/11-archiwum/32-hybris-03 (10.06.2016); J. Baehr Four Varieties of Character-Based Virtue Epistemology, "The Southern Journal of Philosophy" 2008 Vol. 46, No. 4, S. 469-502. Zob. także L. Zagzebski Virtues of the Mind: An Inquiry into the Nature of Virtue and the Ethical Foundations of Knowledge, Cambridge University Press, Cambridge 1996; Virtue Epistemology: Essays on Epistemic Virtue and Responsibility, ed. by A. Fairweather, L. Zagzebski, Oxford University Press, Oxford 2001; E. Sosa A Virtue Epistemology: Apt Belief and Reflective Knowledge, vol. I. Oxford University Press, Oxford 2007; Knowledge, Belief, and Character: Readings in Contemporary Virtue Epistemology, ed. by G. Axtell, Rowman \& Littlefield, Lanham, MD 2000. Ideę epistemologii cnoty jako podstawy odmiennej epistemologii historii zaproponowałam w tekście Metodologia praktyczna, w: E. Domańska Historia egzystencjalna. Krytyczne studium narratywizmu i humanistykizaangażowanej, PWN, Warszawa 2012, s. 176 in. 
Niepostuszeństwo epistemiczne (epistemic disobedience) jest konieczne, by prowokować niepostuszeństwo obywatelskie (Gandhi, Martin Luther King), będąc jego punktem zwrotnym. W ramach nowoczesnej, zachodniej epistemologii nieposłuszeństwo obywatelskie [...] może prowadzić jedynie do reform, lecz nie do transformacji. $Z$ tego też prostego powodu cel myślenia de-kolonialnego i współczesny wariant opcji de-kolonialnej zaczyna się od epistemicznego od-łączenia (de-linking): od aktów epistemicznego nieposłuszeństwa. ${ }^{9}$

Problem sprawiedliwości (i niesprawiedliwości) epistemicznej (i praw epistemicznych - epistemic rights) jest - jak sądzę - tak samo ważny dla Ameryki Łacińskiej i Kanady, skąd docierają do nas szczególnie ożywione dyskusje na ten temat, jak i dla naszego rejonu Europy Środkowo-Wschodniej. Jest tak przede wszystkim dlatego, że z jednej strony dla tzw. ośrodków tworzenia wiedzy, które mieszczą się w Europie Zachodniej i w Stanach Zjednoczonych, jesteśmy prowincją, która co najwyżej dostarcza ciekawych case studies dla testowania tworzonych tam teorii, z drugiej zaś tak samo traktujemy własne "prowincje” czy/i „peryferie”.

Proponuję zatem „podwójną dekolonizację”: zewnętrzną - dekolonizację Polski jako intelektualnej peryferii wobec centrów tworzenia wiedzy; oraz wewnętrzną - dekolonizację małych ośrodków naukowych, muzealnych, kulturalnych jako peryferyjnych wobec akademickich ośrodków flagowych, takich jak Warszawa i Kraków ${ }^{10}$. W takim kontekście podejmowane w ramach „nowej humanistyki” tematy można by traktować jako odzew epistemicznych "peryferii" coraz wyraźniej pretendujących do statusu ważnych ośrodków tworzenia wiedzy. Celem tworzenia wiedzy kierującej się sprawiedliwością epistemiczną „nowej humanistyki” byłoby budowanie „zrównoważonej epistemologii"11, która przyczyniłaby się do neutralizacji uprzywilejowanej

9 Zob.: W.D. Mignolo Epistemic Disobedience, Independent Thought and De-Colonial Freedom, "Theory, Culture \& Society" 2009 Vol. 26, No. 7-8, s. 15. sprawiedliwości świadczenia, które określa ona jako deficyt wiarygodności związany z uprzedzeniami tożsamościowymi (identity-prejudical credibility deficyt). Wiąże to oczywiście zagadnienie niesprawiedliwości epistemicznej z niesprawiedliwością społeczną, M. Fricker Epistemic Injustice..., s. 4. Zob.: A. Pasieka Local Scholars, Global Experts: from a Native's Point of View, "Cargo" 2014, Vol. 12, No. 1/2, s. 51-62.

11 N. Scheman Toward a Sustainable Epistemology, ,Social Epistemology: A Journal of Knowledge, Culture and Policy" 2012 Vol. 26, No. 3/4, s. 471-489. 
pozycji wiedzy zachodniej (i wiedzy tworzonej przez polskie centra) wobec innych rodzajów wiedzy i podejść, które powstały w innych rejonach świata (i Polski) i nie opierają się na jej pryncypiach lub rozumieją owe pryncypia odmiennie, w sposób właściwy dla lokalnych kontekstów tworzenia wiedzy ${ }^{12}$.

Warto zatem potraktować "nową humanistykę" jako laboratorium i w jej ramach poćwiczyć możliwości „epistemicznego nieposłuszeństwa" $i$ „epistemicznego od-łączenia", by użyć terminów Mignolo, od wyuczonej tradycji zachodnio-eurocentrycznej epistemologii. W tym sensie projekt ten włącza się w idee "prowincjonalizowania Europy" jako centrum tworzenia dominującej (i kolonizującej) wiedzy, ale tylko części Europy. Dipesh Chakrabarty podkreśla bowiem, że pisząc Provincializing Europe (2000) nie chodziło mu w istocie o sprowincjonalizowanie Europy, ale o jej re-centralizację. Ma świadomość, że Europ jest w istocie wiele, a sam zainteresowany jest z jednej strony tą, która rości sobie pretensje do tworzenia uniwersalnej wiedzy (ze wszystkimi jej mitami/ideologiami, m.in. postępu, nauki jako dominującego sposobu organizacji wiedzy, sekularyzacji itd.), a z drugiej taką, która jest centrum wielu wiedz lokalnych, podrzędnych ${ }^{13}$. To właśnie one mogą stać się (i już się stają) ważnymi ośrodkami tworzenia wiedzy.

Zagadnienie relacji między nie/sprawiedliwością społeczną i poznawczą staje się dzisiaj w Polsce szczególnie istotne zarówno ze względu na problem polityki historycznej, jak i coraz ciekawsze propozycje płynące ze strony wiedz tworzonych przez różne mniejszości (etniczne, religijne, seksualne). Hasło to wiąże się bowiem z nadal istotnymi kwestiami wewnętrznej dekolonizacji społecznej i politycznej. Warto się zatem zastanowić, jakie nowe podejścia i perspektywy badawcze mogłaby zaproponować „nowa

12 Zob.: J. Goody Kradzież historii, przeł. J. Dobrowolski, PWN, Warszawa 2009; M. Patiniotis, K. Gavroglu The Sciences in Europe: Transmitting Centers and the Appropriating Peripheries, w: The Globalization of Knowledge in History, ed. by J. Renn, Max Planck Research Library for the History and Development of Knowledge, Edition Open Access 2012, s. 321-343; S. Morreira Steps Towards Decolonial Higher Education in Southern Africa? Epistemic Disobedience in the Humanities, "Journal of Asian and African Studies" 2015, S. 1-15 [published online before print March 31, 2015, doi: 10.1177/0021909615577499]; B. De Sousa Santos Epistemologies of the South: Justice Against Epistemicid., Paradigm Publishers, Boulder 2014.

D. Chakrabarty Prowincjonalizacja Europy w czasach globalizacji (przedmowa do wydania z 2007 roku), w: tegoż Prowincjonalizacja Europy. Myśl postkolonialna i różnica historyczna, przeł. D. Kołodziejczyk, T. Dobrogoszcz, E. Domańska, Wydawnictwo Poznańskie, Poznań 2011, s. xiv i n. Por. także M. Patiniotis, K. Gavroglu The Sciences in Europe: Transmitting Centers and the Appropriating Peripheries, w: The Globalization of Knowledge in History, ed. by J. Renn, Max Planck Institute, Berlin 2012. 
humanistyka” inspirowana z jednej strony „literaturami mniejszościowymi” (by użyć określenia Gillesa Deleuze'a i Félixa Guattariego ${ }^{14}$ ) i „przeszłościami podrzędnymi" (Chakrabarty ${ }^{15}$ ), a z drugiej wykorzystywaną przez Fricker filozofią analityczną i epistemologią cnót (manifestującą, jak sądzę, pewne zmęczenie „humanistyką walczącą" i tęsknoty współczesnej humanistyki za obiektywną naukowością i politycznym wyciszeniem).

Od razu jednak podkreślę, że w żadnym razie nie chodzi mi o negowanie tradycji zachodnioeuropejskiej i amerykańskiej humanistyki, która stanowi przecież część naszego intelektualnego dziedzictwa, ani też wagi jej wpływu na kształtowanie się polskiej humanistyki. W żadnym też razie nie jest moim celem promowanie idei romantycznego natywizmu humanistycznego, który w „intelektualnych prowincjach" widzi źródła utraconej wiedzy i wartości oraz głosi chęć podjęcia intelektualnej walki z opresywnymi podejściami badawczymi i teoriami, za pomocą których „imperialna humanistyka zachodnia" kolonizuje polską myśl. Nie namawiam też do intelektualnego nacjonalizmu, tj. do humanistyki narodowej, która promowałaby oryginalne polskie idee jako najlepsze i jedynie właściwe. Chodzi natomiast o udostępnianie i krytyczną recepcję wiedzy tworzonej na Zachodzie i w Stanach Zjednoczonych (zwłaszcza idei, które wydają się nam obecnie awangardowe czy nawet radykalne), o dowartościowanie „wiedz podrzędnych” i intensyfikację procesu ich włączania do tzw. wiedzy mainstreamowej, w czym może pomóc odejście od traktowania tworzonych w centrach teorii jako gotowych do użycia "skrzynek z narzędziami”, a także o bardziej widoczny udział polskich humanistów w toczonych obecnie dyskusjach i promowanie tworzonych przez nich innowacyjnych koncepcji.

\section{Humanistyka prefiguratywna}

Termin humanistyka prefiguratywna proponuję przez analogię do określenia kultura prefiguratywna (prefigurative culture) (i polityka prefiguratywna - prefigurative politics) ${ }^{16}$. Pojęcia „kultura prefiguratywna” użyła amerykańska

G. Deleuze, F. Guattari Kafka: Pour une littérature mineur, Éditions de Minuit, Paris 1975.

D. Chakrabarty Historie mniejszości, przeszłości podrzędne, przeł. E. Domańska, w: tegoż Prowincjonalizacja Europy..., s. 123-143.

Za badacza, który w 1977 roku ukuł pojęcie prefiguracji, uważa się Carla Boggsa. Zob. C. Boggs Marxism, Prefigurative Communism, and the Problem of Workers' Control, "Radical America" 1977 Vol. 11, No. 6, s. 99-122. Zob. także: S.C. Motta Notes Towards Prefigurative Epistemologies, w: 
antropolog Margaret Mead, określając tym mianem typ kultury charakterystyczny dla społeczeństw nowoczesnych, gdzie zmienia się kierunek przekazu wartości - młodsze pokolenia przekazują wzorce kulturowe starszym pokoleniom ${ }^{17}$. Starsze pokolenia muszą przystosowywać się do wzorców wypracowywanych przez pokolenia młodsze, mniej konserwatywne pod względem istniejących już w społeczeństwie norm i wartości. (Obserwacje dzisiejszego młodego pokolenia pozwalają jednak sądzić, że zasada ta obecnie zmienia się). Prowadzi to do kryzysu autorytetów, kanonów i norm, bowiem doświadczenia młodego pokolenia są zasadniczo różne od doświadczeń pokolenia starszego i młodzi nie widzą w nich drogowskazów myślenia i postępowania.

Przez humanistykę prefiguratywną będę tutaj rozumiała taką humanistykę, która jest w stanie wyobrazić sobie przyszłość „zawczasu”; niejako zwiastuje jej nadejście, a jednocześnie bierze udział w kształtowaniu możliwych scenariuszy przyszłości (łac. prae, pre- + łacińskie figūrāre, kształtować; od figüra - kształt) ${ }^{18}$. Cechami ruchów prefiguratywnych nie jest dążenie do przejęcia władzy, ale promowanie horyzontalności i dążenie do zmian, które stymulowane są oddolnie ${ }^{19}$. Ponadto chodzi tu nie tyle o krytykę istniejącego systemu, ile o konkretne eksperymenty w tworzeniu alternatyw dla systemu, który jest uważany (z różnych względów) za wadliwy, niesprawiedliwy; o praktykowanie konkretnych inicjatyw i pokazywanie w ten sposób, że zmiana jest możliwa.

W badaniach prowadzonych w ramach prezentowanych przez nas dziedzin mogłoby to wyglądać tak, że traktujemy humanistykę jako laboratorium

Social Movements in the Global South: Dispossession, Development and Resistance, ed. by S.C. Motta, A. Gunvald Nilsen, Palgrave Macmillan, Basingstoke 2011, s. 178-199; M. Maeckelbergh Doing Is Believing: Prefiguration as Strategic Practice in the Alterglobalization Movement, "Social Movement Studies" 2011 Vol. 10, No. 1, S. 1-20; L. Yates Rethinking Prefiguration: Alternatives, Micropolitics and Goals in Social Movements, "Social Movement Studies" 2015 Vol. 14, No. 1, S. 1-21.

17 Zob. M. Mead Kultura i tożsamość. Studium dystansu międzypokoleniowego, przeł. J. Hołówka, PWN, Warszawa 1978.

"Prefiguracja" wydaje się bardziej interesującym pojęciem od pokrewnego terminu "strategia", który ma militarne konotacje.

Władza nie jest rzeczą, ale ludzkimi relacjami. Przydawanie władzy ludziom to dawanie im możliwości zmiany owych relacji. Rzecz jasna, idea ta obecna jest w znanym haśle "dziel i rządź", ale nie o taką zmianę relacji (tj. o skłócanie ludzi ze sobą w celu bardziej efektywnego sprawowania władzy) mi chodzi. Uważam, że szczególnym zadaniem humanistyki dzisiaj jest łączenie ludzi, a nie ich rozłączanie. 
i szukamy w materiałach historycznych, literaturze, sztuce itd. takich przykładów udanej koegzystencji, łączenia i włączania, które mogłyby stanowić podstawę budowania alternatywnych scenariuszy przyszłości. W takim kontekście sceptycyzm wobec kanonów i autorytetów może okazać się ożywczy. Pomyślmy np., że z Polski (i ogólnie z Europy Środkowo-Wschodniej), podobnie jak to się obecnie dzieje z wiedzą tworzoną w Ameryce Łacińskiej, płynie zasilająca ludzkie poznanie wiedza, która jest budowana nie tyle (nie tylko) na podstawie klasyki, lecz przede wszystkim właśnie na podstawie wspomnianej wyżej literatury (a także sztuki, historii) mniejszościowej. (Podkreślę, że nie proponuję tutaj zastąpienia jednej przez drugą, ale o coś, co można by nazwać „humanistycznym internacjonalizmem”, choć to raczej nie o międzynarodowość chodzi - tak jak jest ona rozumiana w demokracjach, ale o ideę, którą Piotr Piotrowski zawarł kiedyś w haśle „peryferie całego świata, łączcie się!"20).

Trudno w powyższym kontekście nie wspomnieć o utopii. Fredric Jameson zauważył, że „utopia jako forma, nie jest przedstawieniem radykalnych alternatyw; jest raczej nakazem, aby je sobie wyobrażać" ${ }^{\prime 2}$. Zachęca ponadto, by potraktować utopię jako metodę; sposób na odrodzenie myślenia skierowanego ku przyszłości (revival offuturity). Proponuje, by w otaczającej rzeczywistości (często mającej charakter wcielonej dystopii) identyfikować elementy pozytywne i traktować je jako części innego (przyszłościowego) systemu22. Można też zastanowić się, czy mamy na tyle wyobraźni, by wyobrazić sobie alternatywne przyszłości? Jameson jest sceptyczny, uznając,

P. Piotrowski Peripheries of the World Unite!, Paper presented at the XLVI AICA International Congress (Košice - Bratislava, Slovakia, September 24-27, 2013). Maszynopis w posiadaniu autorki.

F. Jameson Utopia as Method or the Uses of the Future, w: Utopia/Dystopia: Conditions of Historical Possibility, ed. by M.D. Gordin, H.Tilley, G. Prakash, Princeton University Press, Princeton, US 2010, s. 42-43. O utopii jako metodzie, a nie celu pisze także Ruth Levitas, Some Varieties of Utopian Method , "Irish Journal of Sociology" 2013 Vol. 21, No. 2, S. 44 oraz tejże Utopia as Method: the Imaginary Reconstitution of Society, Palgrave Macmillan, London 2013. W istocie projekt Jamesona jest podobny do projektu historii potencjalnej zaproponowanego przez izraelską badaczkę i artystkę Ariellę Azoulay. Podejmując problem konfliktu izraelsko-palestyńskiego, Azoulay zaproponowała projekt stworzenia archiwum obywatelskiego (fotograficznego "archiwum historii potencjalnej"), który odrzuca narzucony w latach 1947-1950 podział i ma na celu wydobycie z trudnej przeszłości takich obrazów oraz zaproponowanie odmiennych wobec oficjalnych interpretacji historii, które wskazują na możliwości współbycia Arabów i Żydów. A. Azoulay Potential History: Thinking through Violence, "Critical Inquiry” Spring 2013 Vol. 39, No. 3, s. 548-574. 
że w dzisiejszych czasach, choć dostrzegamy konieczność głębokich zmian, nie widzimy możliwości ich zaistnienia. Mimo tych wątpliwości dyskusja na temat realistycznych utopii, którą tutaj proponuję (a która widoczna jest w ramach humanistyki ekologicznej i antropocenu), stwarza, jak sądzę, przestrzeń do budowania specyficznego rodzaju wiedzy; wiedzy tworzonej „wbrew czasom”, wypełnionej ideami afirmatywnej etyki i polityki (Rosi Braidotti), a także sceptycznego podejścia do tendencji przejawiających się we wszechobecnej reakcyjnej polityce strachu, negatywizmie, nadchodzącej apokalipsie, obezwładniającej traumie, braku, pustce, słabej podmiotowości i pasywnych ofiarach.

Zamiast zatem snuć futurystyczne wizje wyimaginowanych nie-miejsc, które stanowiłyby manifestację pragnień jakichś fantazmatycznych przyszłości, może raczej warto poszukiwać utopii w potencjalności „tu i teraz" i takie istniejące zalążki utopii realnych, realistycznych i odpowiedzialnych próbować rozbudowywać albo/i po prostu budować je w konkretnym środowisku otaczającej codzienności. Proponuje zatem, by zmienić skalę z globalnej i uniwersalnej na lokalną i partykularną, a także podejście utopia nie jest dla mnie fantastyczną reprezentacją, ale konkretnie istniejącym obecnie miejscem; albo miejscem, które jest (w mikroskali) możliwe do zrealizowania. Powtórzę zatem, że skłaniam się ku realistycznym mikroutopiom, które mogą być urzeczywistniane w ograniczonej czasowo i przestrzennie skali lokalnej, jako obowiązujące w określonym czasie, na potrzeby konkretnej społeczności dla wspomożenia dobrostanu jej członków. W sferze dyskursu można myśleć o ich odnajdywaniu lub budowaniu w ramach sterowanej ideami epistemicznej sprawiedliwości humanistyki prefiguratywnej, afirmatywnej, tj. takiej, która w kulturze i życiu społecznym identyfikuje konkretne (często innowacyjne) praktyki i rodzaje relacji mogące stanowić podstawy budowania lepszych modeli wspólnotowości i współbycia.

Współczesna sztuka i humanistyka oraz innowacyjni artyści i badacze odgrywają szczególnie ważną rolę w owej zmianie podejścia do utopii, przygotowując podstawy zmian społecznych. Roland Barthes napisał kiedyś, że „przeszłość narracyjna jest [...] elementem systemu bezpieczeństwa literatury pięknej"23. Czerpiąc inspiracje z Barthes'a, Jakub Muchowski wskazał

23 Barthes zastanawia się na używaniem czasu przeszłego oraz formy trzecioosobowej jako charakterystycznej cechy powieści. Tego typu strategia budowania reprezentacji właściwa jest pisarstwu historycznemu. Stwarza efekt znajomości i wiarygodności opisywanych zdarzeń, 
niedawno, że realizm jako cecha charakterystyczna narracji historycznej także odgrywa rolę systemu bezpieczeństwa. Co więcej, „przekonanie, że przedstawienia historyczne są realistycznym obrazem rzeczywistości i pokazują nam granice możliwości jej transformacji, czyni z historii kryterium prawdopodobieństwa projektów zmiany społecznej"24. Można by zatem powiedzieć, że historia - a nawet szerzej: humanistyka, określa możliwości zmian. Co za tym idzie, modyfikowanie sposobów reprezentacji przeszłości może poszerzać możliwości przyszłych transformacji. Tradycyjne reprezentacje przeszłości (realistyczna narracja charakterystyczna dla XIX-wiecznych powieści) nie były w stanie służyć rozwojowi jednostkowej „wyobraźni moralnej” (koncepcja Johna Deweya) niezbędnej w konstruowaniu odpowiedzialnych utopii (tzn. odpowiedzialnych dla kolektywnego pojmowania wyobrażonego zbiorowo społecznego „horyzontu oczekiwań”, by użyć określenia Reinharta Kosellecka). To właśnie dlatego tak istotne jest budowanie i praktykowanie niekonwencjonalnych reprezentacji przeszłości łamiących reguły rządzące tradycyjnymi sposobami jej badania i przedstawiania. Owe niekonwencjonalne reprezentacje pomagają bowiem tworzyć (a często współtworzą) utopijne wizje przyszłości, które są warunkiem koniecznym społecznych transformacji.

Refleksja nad projektami artystów prowadzi do wniosku, że sztuka współczesna ma kluczowe znaczenie w dyskusji nad „odpowiedzialnymi utopiami”. Na przykład prace Joanny Rajkowskiej są nie tylko krytycznym głosem wobec współczesnych dystopii, nie tyle też pomagają w wymyślaniu nowych utopii, ile często je po prostu tworzą. Warto tutaj przywołać Dotleniacz (2007). Ma on aspekt polityczny (mobilizuje ludzi do podjęcia walki o przestrzeń publiczną), społeczny (tworzy wspólnotę i daje poczucie bycia razem) oraz organiczny (ludzie oddychają świeżym powietrzem). Co jednak najważniejsze, a co przyznaje także Rajkowska, „Dotleniacz jest wcieloną utopią. To jest coś w rodzaju fatamorgany, która działa tylko przez chwilę. Ale jest zarazem bardzo skuteczną, fizycznie działającą fatamorganą [...]"25. W innym miejscu

a jednocześnie daje czytelnikowi poczucie bezpieczeństwa, kiedy odnosi się do przeszłości zamkniętej, dodefiniowanej. R. Barthes Pisanie powieściowe, w: tegoż, Stopień zero pisania, przeł. K. Kot, Aletheia, Warszawa 2009, s. 40. nictwo Naukowe UMK, Warszawa-Toruń 2015, s. 165-166. com/pl/teksty/102 (6.06.2016). Zob. także Dotleniacz/Oxygenator, numer tematyczny pisma "Obieg" $2010 \mathrm{nr} 1-2$. 
artystka deklaruje: „staram się budować bardzo delikatne społeczne relacje na zupełnie podstawowym poziomie. Takim jak, w przypadku Dotleniacza, chwilowe sąsiedztwo, otwieranie przestrzeni publicznej na działania wspólnotowe, choćby tak proste jak uświadomienie sobie, że oddychamy tym samym powietrzem, jesteśmy tu i teraz"26. Jej pracę można, jak sądzę rozważać, jako rodzaj odpowiedzialnej, realnej, lokalnej mikroutopii. Projekt Rajkowskiej sprowadza utopię do konkretnego "tu i teraz” i pokazuje warunki kształtowania się pożądanych re-

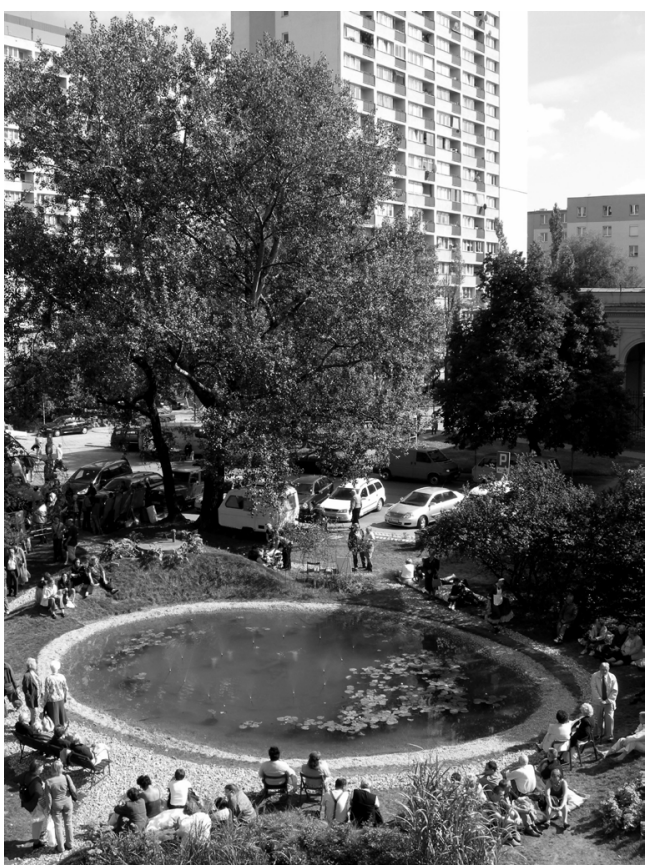

Joanna Rajkowska, Dotleniacz, 2007, fot. Joanna Rajkowska. lacji międzyludzkich. Jest w stanie przekształcić nie tylko miejsce, lecz także stosunki społeczne. Dotleniacz staje się tym samym przykładem prefiguratywnej praktyki społecznej (i sztuki prefiguratywnej), która - wbrew temu, co twierdzi sama artystka, nie jest jednak fantazją czy fatamorganą, ale realną możliwością, choć, rzecz jasna, czasową i miejscową. I może właśnie taka powinna być odpowiedzialna utopia.

\section{Nauka powolna (czy nieśpieszna)}

Badając od lat humanistykę zaangażowaną (nazywaną czasami walczącą militant), już od dłuższego czasu przenika mnie nostalgia za „humanistyką wyciszenia" (określenie Andrzeja Gwoździa), która w spokoju bada, dogłębnie i krytycznie rozważa, „kontempluje” problemy badawcze i tworzy wiedzę

26 J. Rajkowska Dotleniacz. Projekt publiczny (2007), http://www.rajkowska.com/pl/projektyp/64 (6.06.2016). 
w celu jej poszerzenia, zgłębienia i zrozumienia nurtujących współczesność problemów (rzecz jasna, nie chodzi o głoszenie bezwpływowej wiedzy, lecz o wzięcie pod uwagę, że nie wszyscy badacze są bojownikami). Jednocześnie za negatywne uważam procesy umasowienia szkolnictwa, kapitalizacji akademii i jej zamienianie w przedsiębiorstwo (czy korporację) nastawione na zysk przekładający się na mierzalne wyniki.

Deklaracje te z pewnością są bliskie wielu polskim badaczom. Niezadowolenie z obecnej kondycji akademii trwa już oczywiście wiele lat i ma wymiar globalny ${ }^{27}$. Dziesięć lat temu przybrało nawet formę ruchu określanego jako "Slow science movement"28. Idea i nazwa pochodzi od zapoczątkowanego w latach 8o. we Włoszech „The Slow Food movement”, którego celem stało się popularyzowanie zdrowych nawyków żywieniowych, a także celebrowanie lokalnych, odpowiedzialnych środowiskowo kultur żywienia oraz promowanie właściwych praktyk przygotowania i spożywania jedzenia (używanie świeżych produktów; konwersacja przy stole, odpowiednie zachowania itd. $)^{29}$.

We wrześniowym numerze „Nature” z 2006 roku Lisa Alleva, odbywająca staż postdoktorski w School of Biochemistry and Molecular Biology na The Australian National University w Canberra, opublikowała krótki list Taking time to savour the rewards of slow science [Niespieszne delektowanie się korzyściami płynącymi z powolnej nauki]. Alleva pisze tak:

Jako starszy, doświadczony, zatrudniony w niepełnym wymiarze godzin adiunkt, obserwuję wśród moich młodszych, bardziej energicznych współpracowników tendencję wyczerpującego prowadzenia badań aż do nieprzytomności. Podążając za ruchem „slow food”, proponuję przyjąć filozofię „powolnej nauki”, aby rozwiązać ten problem, który moim zdaniem niszczy same podstawy badań naukowych.

Z ostatnio opublikowanych artykułów warto zwrócić uwagę na tekst R.Z. Morawskiego Nauka w czasach biurokracji, w: Inżynier z duszq̨ humanisty, red. K. Baranowski, J. Sośnicka, Wydawnictwo Naukowe Politechniki Łódzkiej, Łódź 2016. Steady Wins the Race, "The Scientist” September 1990 Vol. 4, No. 18, 17, s. 14. gaci z 15 krajów poparli manifest napisany przez członka założyciela - Folco Portinariego. Projekt jest sponsorowany przez EU, http://www.slowfood.com/ (7.06.2016). Zob.: M. Wiśniewska Żywność, życie i turystyka w stylu "slow”, „Zarządzanie i finanse” 2012 Vol. 10, No. 3, S. 161-176. 
Postanowiłam zaakceptować „tu i teraz”. Jestem tutaj, tworzę historię, więc dlaczego z tego nie korzystać? Za sześć czy dwanaście miesięcy, za dwa lata, może mnie tu nie być, ale nie zamierzam harować 100 godzin w tygodniu, aby próbować zrealizować zadania swojego grantu, założyć własne laboratorium czy zrobić habilitację.

Odrzucając ambicję rówieśników, odkryłam tajemnicę: nauka, powolna nauka, jest prawdopodobnie najbardziej satysfakcjonującym i przyjemnym zajęciem, o którym można marzyć. Laboratorium mojego przełożonego jest niewielkie - jest nas tylko dwóch post-doc'ów bez obowiązków dydaktycznych. Mamy czas, by zapoznawać się z fachową literaturą, formułować idee i starannie planować doświadczenia tak, by realizować przemyślane plany prowadzenia badań. Nie przeorujemy genomów w nadziei, że odkryjemy coś ciekawego; formułujemy teorię, a następnie ją testujemy.

Być może jesteśmy staroświeccy, ale czuję, że moje kształcenie jako naukowca w ciągu ostatnich pięciu lat znacznie bardziej skorzystało z powolnej nauki niż w poprzednich pięciu latach z szybkiej (fast science). Co więcej, jesteśmy blisko odkrycia czegoś wielkiego, ekscytującego i wspaniałego; czegoś, co posuwa moją powolną naukę zawsze dalej do przodu. ${ }^{30}$

List ten, a także opublikowane nieco wcześniej artykuły krytykujące pospieszne badania, obniżające jakość i negatywnie wpływające na stopień rzetelności i trafności ich wyników ${ }^{31}$, wywołały wiele dyskusji. W 2010 roku grupa naukowców pracujących w Niemczech i związanych z tzw. „The Slow Science Academy" opublikowała The Slow Science Manifesto, w którym czytamy:

Jesteśmy naukowcami. Nie blogujemy. Nie twittujemy. Nie spieszymy się.

Nie zrozumcie nas źle; mówimy „tak” przyspieszającej nauce początku XXI wieku. Mówimy „tak” stałemu napływowi publikacji, które ukazu-

L. Alleva Taking Time to Savour the Rewards of Slow Science, "Nature” 21 September 2006 No. 443 , S. 271.

31 J.P.A. Ioannidis Why Most Published Research Findings Are False, "PLoS Med” August 2005 Vol. 2, No. 8, [0696-0701] oraz Neal S. Young, John P.A. Ioannidis, Omar Al-Ubaydli, Why Current Publication Practices May Distort Science, „PLoS Med” October 2008 Vol. 5, No. 10, [0002-0004]. 
ją się w recenzowanych czasopismach i ich impaktowi. Mówimy "tak" blogom naukowym, mediom i wymogom PR; mówimy „tak” wzrostowi specjalizacji i różnicowaniu dyscyplin. Mówimy też "tak” badaniom związanym z opieką zdrowotną i przyszłym dobrobytem. Wszyscy mamy w tym udzial.

Uważamy jednak, że to nie wszystko. Nauka potrzebuje czasu do namysłu. Nauka potrzebuje czasu na czytanie i czasu na porażkę. Nauka nie zawsze wie, co w danej chwili należy robić. Nauka rozwija się niepewnie, wykonując gwałtowne ruchy i nieprzewidywalne skoki do przodu. Jednak w tym samym czasie skrada się po bardzo wolnej skali czasowej, na którą musi się znaleźć miejsce i której należy oddać sprawiedliwość.

Powolna nauka przez setki lat była jedyną do pomyślenia opcją. Dzisiaj, jak twierdzimy, zasługuje na odrodzenie i wymaga ochrony. Społeczeństwo powinno dać naukowcom czas, którego potrzebują, lecz także sami naukowcy nie mogą się spieszyć.

Potrzebujemy czasu na myślenie. Potrzebujemy czasu, aby przetrawić [wyniki badań - dop. E.D.]. Potrzebujemy czasu na nieporozumienia, zwłaszcza w celu wspierania utraconego dialogu między humanistyką i naukami przyrodniczymi. Nie możemy ciągle przekonywać, jaki sens ma nasza nauka; po co jest potrzebna, ponieważ po prostu jeszcze tego nie wiemy. Nauka wymaga czasu.

-Prosimy o cierpliwość, kiedy myślimy. ${ }^{32}$

Autorzy manifestu występują przeciwko nauce, od której oczekuje się szybkich rozwiązań problemów społecznych. Jak twierdzą, mechanizmem stymulującym badania powinna być ciekawość badawcza, a nie cele wskazywane przez różnego rodzaju instytucje ${ }^{33}$. Tekst ten wywołał ożywioną

The Slow Science Manifesto (2010), The Slow Science Academy, Berlin, http://slow-science.org/ (7.06.2016). versity of Toronto Press, Toronto 2016. Interesująca w kontekście popularyzacji spowolnienia jest książka psychologa Daniela Kahnemana, który wyjaśnia sposoby myślenia. D. Kahnemana Thinking. Fast and Slow, Macmillan, New York 2011. 
dyskusję, zarówno wspierającą ideę slow science, jak i ją krytykującą. Interesująca jest wypowiedź Rafaela Loyoli, profesora ekologii i ewolucji z Brazylii, który uważa, że tzw. kraje rozwijające się powinny sceptycznie odnieść się do tego ruchu. Loyola, podając przykład Ameryki Łacińskiej (zwłaszcza Brazylii), uważa, że nacisk na publikowanie większej ilości artykułów w ważnych, recenzowanych międzynarodowych czasopismach (high-impact factor journals) powoduje wzrost jakości tworzonej tam wiedzy, budowanie nowych programów studiów doktoranckich, zwiększenie ilości grantów itd. ${ }^{34}$ Inni z kolei obawiają się, że SSM (slow science movement) może legitymizować intelektualne lenistwo, natomiast w istocie chodzi o osiąganie wyższych standardów naukowych ${ }^{35}$.

W kontekście tym interesująco i pioniersko wobec wyżej przytoczonego manifestu lokuje się utworzony w 2009 roku jako „nieformalne centrum badawcze" Wolny Uniwersytet Warszawy (WUW; inicjator: Kuba Szreder; w skład zespołu kuratorskiego wchodzą m.in.: Michał Kozłowski, Jan Sowa, Agnieszka Kurant, Krystian Szadkowski). Operuje on hasłami „wolny, bo powolny” oraz „kultury nie dla zysku”. W deklaracjach zamieszczonych na stronie internetowej Uniwersytetu znajdujemy idee, które są bliskie slow science movement, aczkolwiek samo określenie slow science nie jest tam stosowane, choć występuje określenie slow culture. Czytamy tam m.in., że „WUW jest reakcją nie tyle na tempo tworzenia kultury, lecz przede wszystkim na próby jego odgórnego uregulowania poprzez gonitwę projektów i niekończącą się paradę aplikacji". W odróżnieniu jednak od jej odpowiedników WUW broni się przed stabilizującym ulokowaniem, deklarując, że „działając równolegle wobec oficjalnych ośrodków edukacji artystycznej i uniwersyteckiej" jest instytucją „sieciową i nomadyczną"; głosi także otwartą edukację i udostępnianie wiedzy w trybie open access $^{36}$. Idea WUW jest zatem znacznie szersza (i społecznie oraz politycznie zaangażowana) od ruchu slow science, który stanowi jeden z aspektów działalności Wolnego Uniwersytetu.

34 R. Loyola Developing Nations Should Avoid "Slow Science", "SciDevNet" 01/05/13, http:// www.scidev.net/global/r-d/opinion/developing-nations-should-avoid-slow-science-.html (25.06.2016).

35 S. Magela Thomaz, R.P. Mormul Misinterpretation of "Slow Science" and "Academic Productivism" may Obstruct Science in Developing Countries, "Brazilian Journal of Biology” 2014 Vol. 74, No. 3 (suppl.), s. 1-2. Zdaniem autorów idea slow science jest myląca, a określenie deep science byłoby bardziej odpowiednie.

36 Wolny Uniwersytet Warszawy, http://www.wuw-warszawa.beczmiana.pl/oprojekcie.php (10.07.2016). 


\section{Zakończenie}

Prezentowany tekst jest gęsty i zawiera różnorodne pomysły wymagające krytycznych analiz konkretnego materiału badawczego, które pokazałyby ich przydatność. Kieruje mną być może jakiś „zew przyszłych przodków” i zastanawiam się, czy i jak można obecnie budować taką wiedzę o historii, literaturze, sztuce, która nie rościłaby sobie pretensji do wieszczenia przyszłości, lecz na nią wpływała - pre-figurowała (tworzyła realistyczne utopie lokalne), zdając sobie sprawę, że niecały plan się uda albo że może nie udać się wcale. Przez takie pomysły wpadam jednak we własne sidła: z jednej bowiem strony tęsknię za „humanistyką wyciszenia” (której elementem jest „powolna nauka” powracająca do idei budowania nauki obiektywnej, „rozważanej”), z drugiej zaś widzę zasadność dalszego promowania humanistyki zaangażowanej, która rzecz jasna, nie jest bezstronna. Zaangażowanie może być mimo wszystko wyważone i etyczne i kierować się dyrektywami sprawiedliwości epistemicznej, co jednak wymaga dużej autodyscypliny badawczej (epistemologia cnoty). Włączenie zatem idei sprawiedliwości epistemicznej jako zasady sterującej badaniami prowadzonymi w ramach humanistyki zaangażowanej przydałoby jej - jak sądzę - rozwagi (a może nawet mądrości). 


\section{Abstract}

\section{Ewa Domańska}

ADAM MICKIEWICZ UNIVERSITY (POZNAŃ)

Epistemic /ustice in the Engaged Humanities

This article examines how the idea of'slow science' (which privileges quality of research and the formative role of teaching and of conducting scientific research) correlates with the question of epistemic justice and the future-oriented prefigurative humanities. Domańska argues that epistemic justice should be recognized as both a directive that steers research undertaken in this framework, and as a tool in the construction of realistic and responsible utopias, whose prototypes the'New Humanities' are trying to find in art, literature, film, etc. The notion of such a utopia being a repeatable solution to a scientific problem can become a research method characteristic of the 'New Humanities'.

\section{Keywords}

prefigurative humanities, epistemic justice, slow science, apotropaic texts, utopia 